\title{
A Model of Corporate Social Responsibility, Firm Reputation, and Firm Performance in Small and Medium Enterprises in Kaski, Lamjung, and Gorkha District of Gandaki Province, Nepal
}

\author{
Bijay Sigdel, Fuangfa Amponstira \\ School of Management, Shinawatra University, Bangkok, Thailand \\ Email: sigdelbijayy@gmail.com, fuangfa.a@siu.ac.th
}

How to cite this paper: Sigdel, B., \& Amponstira, F. (2021). A Model of Corporate Social Responsibility, Firm Reputation, and Firm Performance in Small and Medium Enterprises in Kaski, Lamjung, and Gorkha District of Gandaki Province, Nepal. Open Journal of Business and Management, 9, 2248-2260.

https://doi.org/10.4236/ojbm.2021.95121

Received: July 13, 2021

Accepted: September 3, 2021

Published: September 6, 2021

Copyright $\odot 2021$ by author(s) and Scientific Research Publishing Inc. This work is licensed under the Creative Commons Attribution International License (CC BY 4.0).

http://creativecommons.org/licenses/by/4.0/

(c)

\begin{abstract}
The study's objective is to create a model and mediating role of firm reputation in the relationship between corporate social responsibility (CSR) and the performance of small and medium enterprises (SME). The quantitative research design was used to collect data via telephone and e-mail with 232 small and medium enterprises. The sample for the study was done by using stratified sampling where Kaski, Gorkha, and Lamjung district of Gandaki province are selected. The analysis was done using Statistical Package for Social Science (SPSS) 26 and Applied Structural Equation Modeling (AMOS) 24 software. The study found that legal and ethical responsibilities have a significant positive relationship with the performance of SMEs and a firm's reputation. Also, there is a significant positive relationship between a firm's reputation and the performance of small and medium enterprises. Finally, the study shows that a firm's reputation mediates the relationship between legal and ethical responsibilities on SME performance. In the structural model, environmental responsibilities have a relationship with performance. Likewise, philanthropic, and economic responsibilities have a relationship with the firm's reputation, thus creating a new model in this study.
\end{abstract}

\section{Keywords}

Firm's Reputation, Corporate Social Responsibility, Performance, Small and Medium Enterprises, Structural Model 


\section{Introduction}

Corporate social responsibility (CSR) helps business organizations increase customer retention and maintain a good and effective relationship with local institutes (Sigdel \& Amponstira, 2020). The organization's performance is measured to make sure that the company is able to achieve the targeted goal and objective with the right direction (Bhatti, Awan, \& Razaq, 2014). The industrial enterprises act 2016 of Nepal stated that there is mandatory to contribute at least one percent of the annual profit to corporate social responsibility by small, medium, and large enterprises (Nepal Government, 2020). The importance of firm reputation in a business organization is increasing due to the public awareness about action and issues related to cooperation, higher expectation of stakeholder's, online communication, personal experience of customer on the product or services that increases the importance of managing the corporate reputation (Shamma, 2012). The organization's performance is determined by the actual output that is measured against the intended outcome of the organization (Gyanwali \& Walsh, 2020).

The reasons for investigating CSR and Small and Medium enterprises are the involvement of Micro, Small, and Medium Enterprises (MSMEs) of Nepal up to 70 - 80 percentage in industrial production and 80 percentage in generating employment (Forest Connect, 2009). The supports of Micro, Small, and Medium Enterprises (MSMEs) increase the establishment of new industries and create new jobs for the local people (Forest Connect, 2009). In the context of Nepal, the percentage of the unemployment rate of $2018 / 19$ is 11.4 percentage, and the percentage of the population under poverty in $2018 / 19$ is 18.7 percentage (Government of Nepal, 2019). Moreover, the environmental performance index of Nepal is being ranked 145th out of 180 with an overall score of 32.7 around the world (EPI, 2020). The above data shows the social, environmental, and economic realities, so that the paper used the CSR dimensions (Environmental, Economic, Legal, Ethical, and Philanthropic responsibilities) in the context of Nepal.

The strength of this paper is that there are numerous researches on corporate social responsibility and business (Pant \& Piansoongnern, 2017; Adhikari et al., 2016), but there is a lack of study in reputation and performance of the organization that is fulfilled by this paper. And the result of this paper can be used by small and medium enterprises owners or managers to improve the performance of the enterprises. The objective of the study is to create a model and mediating role of firm reputation in the relationship between corporate social responsibility and performance of small and medium enterprises. The paper follows the pattern of first, the introduction followed by literature review, methodology, result and discussion, conclusion, and recommendation.

\section{Literature Review}

This section explains the relationship between corporate social responsibility, a firm's reputation, and a firm's performance. 


\subsection{Corporate Social Responsibility and Firm's Performance}

Most of the research has stated that corporate social responsibility is essential to increase firm performance (Russo \& Fouts, 1997; Gatti et al., 2012; Surroca et al., 2010). There is a significant increment of business firms by implementing corporate social responsibility (Singh et al., 2017). But (Brammer et al., 2006) stated a negative relationship between corporate social responsibility and firm performance, and (Teoh et al., 1999) mentioned that there is no relationship between the firm's performance and corporate social responsibility. To have success and achieve the objective of the firm, there is the importance of corporate social responsibility Stainer (2006). The customer attention should be performed for the firm's success that is possible by contributing to the sector that is related to the development of the society (Lev et al., 2010).

$\mathrm{H} 1$ : There is a significant positive effect of corporate social responsibility on SME performance.

\subsection{Corporate Social Responsibility, Firm Reputation, and Firm Performance}

Numerous researches have stated a positive relationship between corporate social responsibility and the firm reputation of a business organization (Lai et al., 2010; Stanaland et al., 2011; Maden et al., 2012). The activities of corporate social responsibilities represented in the annual report of the organization have a significant positive relationship with the performance of the firm and corporate reputation (Arshad et al., 2012). In addition, the organization which provides charity and donation to the society helps to increase the positive impact in firm's reputation (Fombrun \& Shanley, 1990). In research, (Saeidi et al., 2015) stated that there is a mediating effect of corporate reputation in the relationship between corporate social responsibility and the performance of the business. But (Sindhu \& Arif, 2017) stated that there is a partial mediation of corporate reputation on the relationship between corporate social responsibility and business performance.

$\mathrm{H} 2$ : There is a significant positive effect of corporate social responsibility on a firm's reputation.

H4: Firm reputation mediates the relationship between corporate social responsibility and SME performance.

\subsection{Firm's Reputation and Firm's Performance}

Most of the researchers have identified a positive relationship between firm reputation and performance (Fombrun \& Shanley, 1990; Dunbar \& Schwalbach, 2000; Hall \& Lee, 2014). But in research, (Inglis et al., 2006) show that there is no relationship between corporate reputation and firm performance. On the other hand, the result of the study by (Lee \& Roh, 2012) stated that there is a significant positive relationship between reputation and performance of business enterprises. Also, (Li et al., 2016) state that corporate reputation has a significant 
positive relationship with enterprise growth.

H3: There is a significant positive effect of a firm's reputation on SME performance.

From the above discussion it is concluded that there is a relationship between corporate social responsibility, firm reputation, and firm performance. However, there is limited study on the mediating role of firm reputation in the relationship between corporate social responsibility and performance of small and medium enterprises. Thus, this study will fulfill the research gap.

\section{Methodology}

The study's objective is to create a model and mediating role of firm reputation in the relationship between corporate social responsibility and performance of small and medium enterprises. The method used in the study is quantitative research design, and data is collected by using e-mail and telephone contact. The research population was collected from the Chamber of Commerce and Industry in Gandaki province of Nepal. The sample for the research was done by using stratified sampling where Kaski, Gorkha, and Lamjung district of Gandaki province were selected. A rule of thumb for critical sample size is 200 that provides stable parameter estimates and has sufficient power to test a model (Collier, 2020). While applying (Yamane, 1967; Israel, 1992) with $\pm 7 \%$ precision level where level of confidence is $95 \%$ and $P=0.5$ thus, the sample for the study is 232 small and medium enterprises. The variables used in this study of corporate social responsibility are ethical, legal, philanthropic, economic (Carroll, 1991), and environmental responsibilities (Lee et al., 2019). Similarly, the variable of firm reputation is quality of employee, customer orientation or focus, quality of management (Schwaiger, 2004), and firm performance are product and service quality, customer retention, effectiveness (Spillan \& Parnell, 2006). The item objective congruence (IOC) tests the questionnaire by experts before going to the data collection process.

Initially, this study does not have a missing value and suspicious response pattern; however, while doing Mahalanbis Distance (D2), the respondents 39, 40, $85,92,109$, and 138 are detected as the outliner, and they were deleted using 0.005 level of significance (Hair et al., 2014). Therefore, the usable respondents of the study are 226. The Cronbach alpha should be more than 0.70 (Nunnally, 1978) for acceptance, and the result of the study is 0.788. After that, demographic analysis is conducted. The further steps are analyzing the measurement model and structural model using version 26 of Statistical Package for Social Science (SPSS) and version 24 of Applied Structural Equation Modeling (AMOS) software. The model fit values are, $p$-value $>0.05$, Goodness of Fit Index (GFI) $>$ 0.90, Root mean square error of approximation (RMSEA) between $0.05-0.08$ or less, Chi-squares and degree of freedom (Chisq/df) $<3.0$, Incremental Fit Index (IFI) 0.90 and Comparative Fit Index (CFI) $>0.90$ (Hooper et al., 2008; Burkhalter et al., 2010; Schreiber et al., 2006). 


\section{Result and Discussion}

This section explains respondent profile, confirmatory factor analysis, path analysis, mediating effect, and structural equation modeling to meet the study's objective.

\subsection{Respondent Profile}

In the study, the respondent mainly male 66.8 percentage and females, 33.2 percentage. The respondent's position in the firms is 97.3 percentage are owner, whereas 2.7 percentage are the manager. The study covers the 58.4 respondents from Kaski district, 31 percentage from Lamjung district, and 10.6 percentage from Gorkha district. The respondent is more involved in small enterprises 91.2 percentage rather than medium 8.8 percentage. The data shows that more enterprises are based on manufacturing 41.6 percentage, subsequently service 16.8 percentage, tourism 16.4 percentage, agro/forestry 23.5 percentage, and construction 1.8 percentage.

\subsection{Confirmatory Factor Analysis}

Confirmatory factor analysis (CFA) is the relationship between the latent variable and observed measure Brown \& Moore (2012). Figure 1 shows confirmatory factor analysis 1 with factor loading and fitness of the model.

Figure 1 shows a positive relationship between latent variable environmental responsibilities with observed variables ENV1, ENV2, ENV3, and ENV4. The

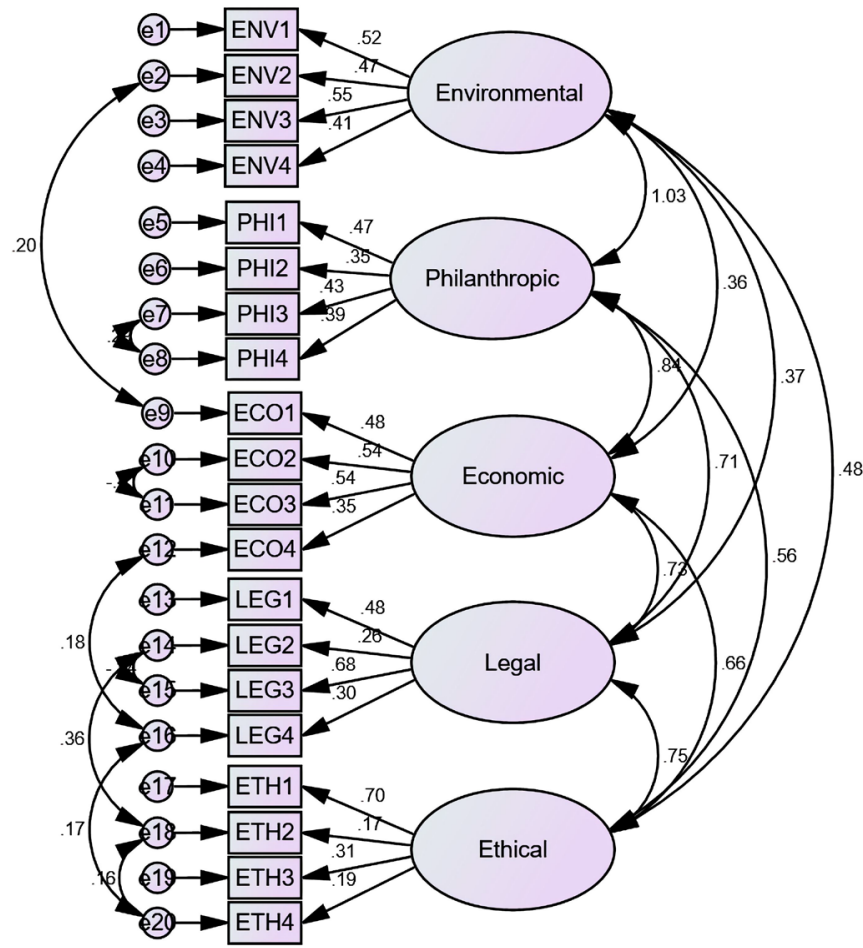

$P$ value- 0.054

CMIN/DF- 1.191

GFI- 0.927

CFI- 0.946

IFI- 0.950

RMSEA- 0.029

Figure 1. Confirmatory factor analysis 1 . 
higher factor loading is in ENV3 (0.55) followed by ENV1 (0.52), ENV2 (0.47) and ENV4 (0.41) respectively. Similarly, the relationship between latent variable philanthropic responsibilities has a positive relationship with observed variable PHI1, PHI2, PHI3, and PHI4, where the higher factor loading is in PHI1 (0.47) followed by PHI3 (0.43), PHI4 (0.39), and PHI2 (0.35) respectively. And latent variable economic responsibilities have a positive relationship with observed variable $\mathrm{ECO} 1, \mathrm{ECO} 2, \mathrm{ECO} 3$, and $\mathrm{ECO}$. The higher factor loading is in $\mathrm{ECO} 2$ (0.54), ECO3 (0.54), followed by ECO1 (0.48) and ECO4 (0.35), respectively. Likewise, there is a positive relationship between latent variable legal responsibilities with observed variable LEG1, LEG2, LEG3, and LEG4. The higher factor loading is in LEG3 (0.68), followed by LEG1 (0.48), LEG4 (0.30), and LEG2 (0.26), respectively. Also, the relationship between latent variable ethical responsibilities has a positive relationship with observed variables ETH1, ETH2, ETH3, and ETH4. The higher factor loading is in ETH1 (0.70) followed by ETH3 (0.31), ETH4 (0.19) and ETH2 (0.17) respectively. The output value after modification of model is $P$-value 0.054 , CMIN/DF 1.191, GFI 0.927, CFI 0.946, IFI 0.950, and RMSEA 0.029 which accept the criteria; as a result, the model is accepted. Similarly, Figure 2 shows Confirmatory Factor Analysis 2 with factor loading and fitness of the model.

Figure 2 shows that there is a positive relationship between latent variable firm's reputation and observed variable REP1, REP2, and REP3. The higher factor loading is in REP2 (0.16) followed by REP3 (0.13) and REP1 (0.12), respectively. And the relationship between latent variable SMEs performance has a positive relationship with observed variable PER1, PER2, and PER3. The higher factor loading is in PER2 (0.51) followed by PER1 (0.42) and PER3 (0.24), respectively. The output value after modification of model is P-value 0.094, CMIN/DF 1.805, GFI 0.985, CFI 0.927, IFI 0.936, and RMSEA 0.060 which accept the criteria; as a result, the model is accepted.

\subsection{Path Analysis}

Path analysis helps to understand the strength of the relationship between the variables and enables the researcher to confirm and disconfirm of hypothesis Lleras (2005). Figure 3 shows that the path from environmental responsibilities

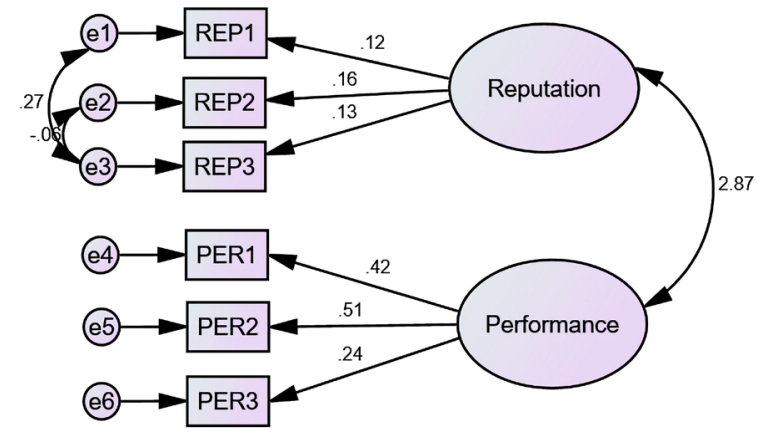

$\mathrm{P}$ value- 0.094 CMIN/DF- 1.805 GFI- 0.985 CFI- 0.927 IFI- 0.936 RMSEA- 0.060

Figure 2. Confirmatory factor analysis 2 . 


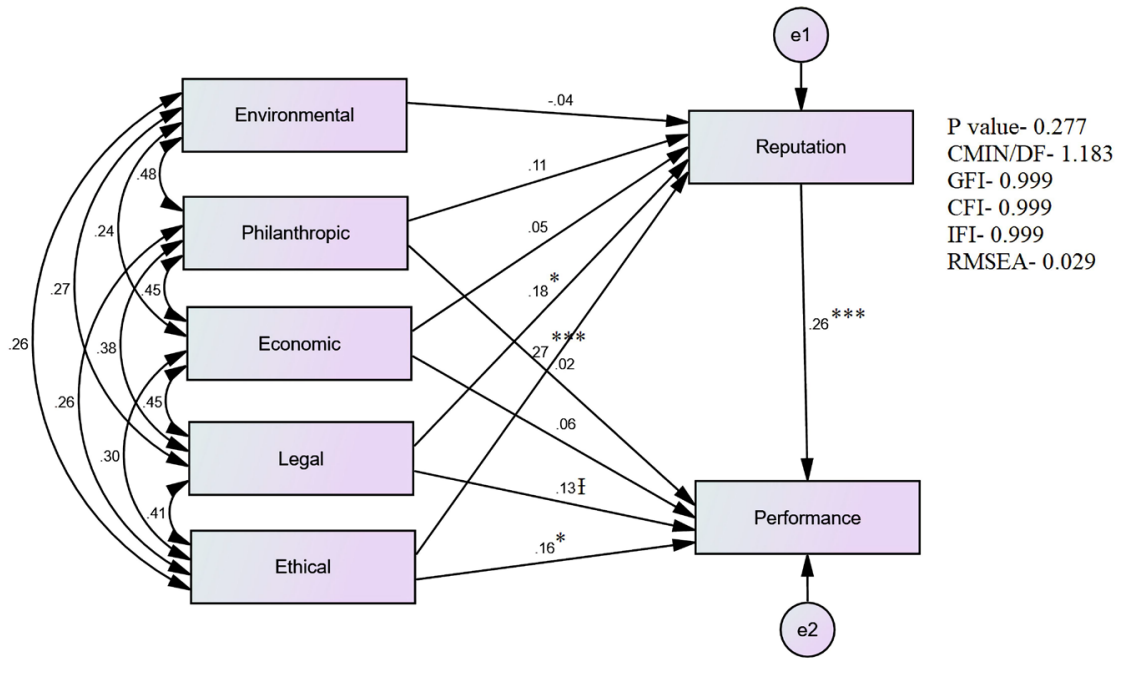

*** Significance value $<0.001 * *$ Significance value $<0.010 *$ Significance value $<0.050$ f Significance value $<0.100$

Figure 3. Path analysis.

to performance is deleted due to a lower path coefficient of -0.07 . Legal responsibilities positively affect SME's performance and significant at less than ten percent $(\beta=0.128, p<0.100)$. Thus, H1d that states that legal responsibilities have a significant positive effect on SME's performance are supported. Ethical responsibilities have a positive effect on the performance of SMEs and significant at less than five percent $(\beta=0.156, p<0.050)$. Thus, H1e that states that ethical responsibilities have a significant positive effect on firm performance are supported.

Legal responsibilities have a positive effect on the reputation of SMEs and significant at less than five percent $(\beta=0.184, p<0.050$ ). Thus, H2d that states that Legal responsibilities have a significant positive effect on a firm's Reputation are supported. Ethical responsibilities have a positive effect on the reputation of SMEs and significant at less than 0.1 percentage $(\beta=0.271, p<0.001)$. Thus, H2e states that Ethical responsibilities have a significant positive effect on a firm's reputation is supported. The firm's reputation has a positive effect on the performance of the SME's and significant at less than 0.1 percentage $(\beta=0.262$, $p<0.001)$. Thus, $\mathrm{H} 3$ states that a firm's reputation has a significant positive effect on SME's performance is supported. The output value after modification of model is P-value 0.277, CMIN/DF 1.183, GFI 0.999, CFI 0.999, IFI 0.999, and RMSEA 0.029 which accept the criteria; as a result, the model is accepted.

\subsection{Mediating Effect}

The third variable that occurs in between two other connected construct variables is stated as a mediating variable Hair et al. (2016). Table 1 shows that a firm's reputation mediates the relationship between legal responsibilities and the performance of the SME's, with significance at less than one percent $(\beta=0.048$, $p<0.010$ ). Thus, H4d states that a firm's reputation mediates the relationship 
between legal responsibilities and SME performance. Also, the firm's reputation mediates the relationship between ethical responsibilities and performance of the SME's, significance at less than 0.1 percentage $(\beta=0.071, p<0.001)$. Thus, $\mathrm{H} 4 \mathrm{e}$ states that a firm's reputation mediates the relationship between ethical responsibilities and SME's performance.

Table 1 shows that a firm's reputation mediates the relationship between legal responsibilities and the performance of the SME's, with significance at less than one percent $(\beta=0.048, p<0.010)$. Thus, H4d states that a firm's reputation mediates the relationship between legal responsibilities and SME performance. Also, the firm's reputation mediates the relationship between ethical responsibilities and performance of the SME's, significance at less than 0.1 percentage $(\beta=$ $0.071, p<0.001)$. Thus, H4e states that a firm's reputation mediates the relationship between ethical responsibilities and SME's performance. Table 2 shows the comprehensive summarization of hypothesis testing.

\subsection{Structural Equation Modeling}

The Coefficient of Determination (R2) value is used to measure the structural model (Hair et al., 2016). Figure 4 shows that $\mathrm{R} 2=0.08$ of a firm's reputation

Table 1. Mediating effect.

\begin{tabular}{lc}
\hline \multicolumn{1}{c}{ Indirect Path } & Standardized Estimate \\
\hline Philanthropic $-->$ Reputation $-->$ Performance & 0.029 \\
Economic $-->$ Reputation $-->$ Performance & 0.013 \\
Legal --> Reputation --> Performance & $0.048^{\star *}$ \\
Ethical --> Reputation --> Performance & $0.071^{* * *}$ \\
Environmental --> Reputation --> Performance & -0.009 \\
\hline
\end{tabular}

${ }^{* *}$ Significance value $<0.001,{ }^{*}$ Significance value $<0.010$.

Table 2. Summary of hypothesis testing.

\begin{tabular}{lc}
\hline \multicolumn{1}{c}{ Hypothesis } & Results \\
\hline H1: Corporate Social Responsibility --> SME performance. & Rejected \\
H1a: Environmental responsibilities --> SME performance. & Rejected \\
H1b: Philanthropic responsibilities --> SME performance. & Rejected \\
H1c: Economical responsibilities --> SME performance. & Accepted \\
H1d: Legal responsibilities --> SME performance. & Accepted \\
H1e: Ethical responsibilities --> SME performance. & Rejected \\
H2: Corporate Social Responsibility --> Firm reputation. & Rejected \\
H2a: Environmental responsibilities --> Firm reputation. & Rejected \\
H2b: Philanthropic responsibilities --> Firm reputation. & \\
H2c: Economical responsibilities --> Firm reputation. &
\end{tabular}




\section{Continued}

H2d: Legal responsibilities --> Firm reputation.

Accepted

H2e: Ethical responsibilities --> Firm reputation.

Accepted

H3: Firm reputation --> SME performance.

Accepted

H4: Corporate Social Responsibility --> Firm reputation --> SME performance

H4a: Environmental responsibilities --> Firm reputation --> SME performance.

Rejected

H4b: Philanthropic responsibilities --> Firm reputation --> SME performance.

Rejected

H4c: Economical responsibilities --> Firm reputation --> SME performance.

Rejected

H4d: Legal responsibilities --> Firm reputation --> SME performance.

Accepted

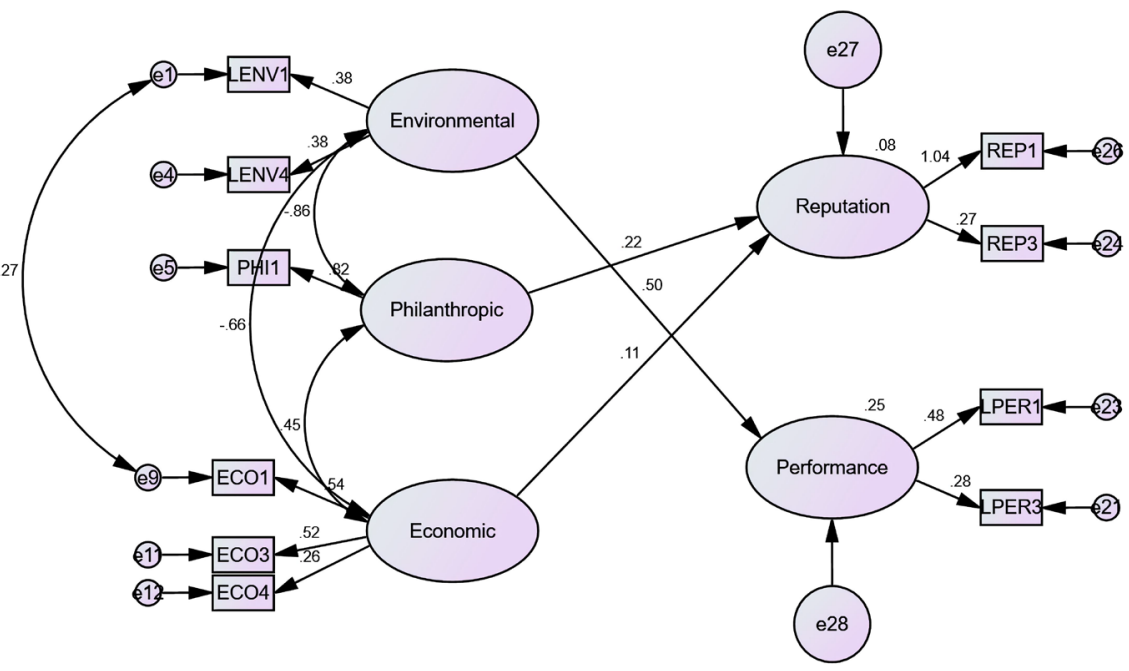

P value- 0.101, CMIN/DF- 1.352, GFI- 0.967, CFI- 0.921, IFI- 0.931, RMSEA- 0.040

Figure 4. Structural equation modeling.

denotes an 8 percent variation in the firm's reputation due to philanthropic and economic responsibilities. The value $\mathrm{R} 2=0.08$ of firm reputation is considered very weak. The value $\mathrm{R} 2=0.25$ of SMEs performance denotes a 25 percent variation in firm performance due to environmental responsibilities. The value $\mathrm{R} 2=$ 0.25 of firm performance is considered weak. In this model, environmental responsibilities have a relationship with SME performance. And philanthropic and economic responsibilities have a relationship with the firm's reputation. The output value after modification of model is P-value-0.101, CMIN/DF-1.352, GFI-0.967, CFI-0.921, IFI-0.931, and RMSEA-0.040 which accept the criteria; as a result, the model is accepted.

\section{Conclusion and Recommendation}

This study shows that only legal and ethical responsibilities have significant positive effects on SME's performance in the same way; (Basuony et al., 2014) also indicate that ethical, economic, legal, and discretionary responsibilities have a 
positive relationship with firm performance. Whereas the study (Guzman et al., 2016) show that variables of corporate social responsibility are environmental, social, and economic responsibilities have a significant positive relationship with the performance of the business. Similarly, this study shows that legal and ethical responsibilities have a significant positive effect on a firm's reputation, which is also accepted by the study (Ali \& Ali, 2011; Maden et al., 2012). Likewise, this study shows that firm reputation has a significant positive effect on SME's performance which is also justified in the study (Agyemang \& Ansong, 2017; Hall \& Lee, 2014). The study (Saeidi et al., 2015; Sindhu \& Arif, 2017) states that firm reputation mediates the relationship between corporate social responsibility and firm performance; however, this study concludes that CSR dimension legal and ethical responsibilities have the mediating effect of firm's reputation on SMEs performance.

In the structural model, environmental responsibilities have a relationship with SME performance. Likewise, philanthropic, and economic responsibilities have a relationship with the firm's reputation, thus creating a new model. This study recommends SMEs focus on legal and ethical responsibilities to increase the firm's reputation so that the performance of SMEs will be better. This study develops a new model which can be the scope for further study. This study is based on the limited areas/district, which cannot represent all SMEs of Nepal, so further studies can increase the sample size.

\section{Conflicts of Interest}

The authors declare no conflicts of interest regarding the publication of this paper.

\section{References}

Adhikari, D. R., Gautam, D. K., \& Chaudhari, M. K. (2016). Corporate Social Responsibility Domains and Related Activities in Nepalese Companies. International Journal of Law and Management, 58, 673-684. https://doi.org/10.1108/IJLMA-08-2015-0044

Agyemang, O. S., \& Ansong, A. (2017). Corporate Social Responsibility and Firm Performance of Ghanaian SMEs. Journal of Global Responsibility, 8, 47-62. https://doi.org/10.1108/JGR-03-2016-0007

Ali, I., \& Ali, J. F. (2011). Corporate Social Responsibility, Corporate Reputation and Employee Engagement. MPRA Paper No. 33891, Munich Personal RePEc Archive.

Arshad, R., Othman, S., \& Othman, R. (2012). Islamic Corporate Social Responsibility, Corporate Reputation and Performance. World Academy of Science, Engineering and Technology, 64, 1070-1074.

Basuony, M. A., Elseidi, R. I., \& Mohamed, E. K. (2014). The Impact of Corporate Social Responsibility on Firm Performance: Evidence form a MENA Country. Corporate Ownership \& Control, 12, 761-774. https://doi.org/10.22495/cocv12i1c9p1

Bhatti, M. I., Awan, H. M., \& Razaq, Z. (2014). The Key Performance Indicators (KPIs) and Their Impact on Overall Organizational Performance. Quality \& Quantity, 48, 3127-3143. https://doi.org/10.1007/s11135-013-9945-y 
Brammer, S., Brooks, C., \& Pavelin, S. (2006). Corporate Social Performance and Stock Returns: UK Evidence from Disaggregate Measures. Financial Management, 35, 97-116. https://doi.org/10.1111/j.1755-053X.2006.tb00149.x

Brown, T. A., \& Moore, M. T. (2012). Confirmatory Factor Analysis. In R. H. Hoyle, Ed., Handbook of Structural Equation Modeling (pp. 361-379), Guilford Press.

Burkhalter, H., Sereika, S. M., Engberg, S., Wirz-Justice, A., Steiger, J., \& Geest, S. D. (2010). Structure Validity of the Pittsburgh Sleep Quality Index in Renal Transplant Recipients: A Confirmatory Factor Analysis. Sleep and Biological Rhythms, 8, 274-281. https://doi.org/10.1111/j.1479-8425.2010.00473.x

Carroll, A. B. (1991). The Pyramid of Corporate Social Responsibility: Toward the Moral Management of Organizational Stakeholders. Business Horizons, 34, 39-48. https://doi.org/10.1016/0007-6813(91)90005-G

Collier, J. E. (2020). Applied Structural Equation Modeling Using AMOS: Basic to Advanced Techniques. Routledge. https://doi.org/10.4324/9781003018414

Dunbar, R. L., \& Schwalbach, J. (2000). Corporate Reputation and Performance in Germany. Corporate Reputation Review, 3, 115-123.

https://doi.org/10.1057/palgrave.crr.1540106

EPI (2020). Environmental Performance Index. https://epi.yale.edu/epi-results/2020/country/npl

Fombrun, C., \& Shanley, M. (1990). What's in a Name? Reputation Building and Corporate Strategy. Academy of management Journal, 33, 233-258.

https://doi.org/10.5465/256324

Forest Connect (2009). Challenges and Opportunities for Nepal's Small and Medium Forest Enterprises (SMFEs). Food and Agriculture Organization of The United Nations.

Gatti, L., Caruana, A., \& Snehota, I. (2012). The Role of Corporate Social Responsibility, Perceived Quality and Corporate Reputation on Purchase Intention: Implications for Brand Management. Journal of Brand Management, 20, 65-76. https://doi.org/10.1057/bm.2012.2

Government of Nepal (2019). Economic Survey 2018/19. Ministry of Finance.

Guzman, G. M., Castro, S. Y., \& Torres, G. C. (2016). Corporate Social Responsibility and Business Performance: The Role of Mexican SMEs. International Journal of Asian Social Science, 568-579. https://doi.org/10.18488/journal.1/2016.6.10/1.10.568.579

Gyanwali, S., \& Walsh, J. C. (2020). Influencing Factors of Organizational Performance in Nepal Airlines Corporation. International Business Research, 13, 268-283. https://doi.org/10.5539/ibr.v13n1p268

Hair, Jr., J. F., Black, W. C., Babin, B. J., \& Anderson, R. E. (2014). Multivariate Data Analysis (7th ed.). Pearson New International Edition.

Hair, Jr. J. F., Hult, G. T., Ringle, C. M., \& Sarstedt, M. (2016). A Primer on Partial Least Squares Structural Equation Modeling (PLS-SEM). Sage Publications. https://doi.org/10.15358/9783800653614

Hall, E. H., \& Lee, J. (2014). Assessing the Impact of Firm Reputation on Performance: An International Point of View. International Business Research, 7, 1. https://doi.org/10.5539/ibr.v7n12p1

Hooper, D., Coughlan, J., \& Mullen, M. R. (2008). Structural Equation Modelling: Guidelines for Determining Model Fit. Electronic Journal on Business Research Methods, 6, 53-60. 
Inglis, R., Morley, C., \& Sammut, P. (2006). Corporate Reputation and Organisational Performance: An Australian Study. Managerial Auditing Journal, 21, 934-947. https://doi.org/10.1108/02686900610705028

Israel, G. D. (1992). Determining Sample Size. University of Florida Cooperative Extension Service, Institute of Food and Agricultural Sciences.

Lai, C.-S., Chiu, C.-J., Yang, C.-F., \& Pai, D.-C. (2010). The Effects of Corporate Social Responsibility on Brand Performance: The Mediating Effect of Industrial Brand Equity and Corporate Reputation. Journal of Business Ethics, 95, 457-469. https://doi.org/10.1007/s10551-010-0433-1

Lee, J., \& Roh, J. J. (2012). Revisiting Corporate Reputation and Firm Performance Link. Benchmarking: An International Journal, 19, 649-664.

https://doi.org/10.1108/14635771211258061

Lee, S. S., Kim, Y., \& Roh, T. (2019). Modified Pyramid of CSR for Corporate Image and Customer Loyalty: Focusing on the Moderating Role of the CSR Experience. Sustainability, 11, 47-45. https://doi.org/10.3390/su11174745

Lev, B., Petrovits, C., \& Radhakrishnan, S. (2010). Is Doing Good for You? How Corporate Charitable Contributions Enhance Revenue Growth. Strategic Management Journal, 31, 182-200. https://doi.org/10.1002/smj.810

Li, H. G., Chen, Z. W., \& Ma, G. X. (2016). Corporate Reputation and Performance: A Legitimacy Perspective. Entrepreneurial Business and Economics Review, 4, 181. https://doi.org/10.15678/EBER.2016.040313

Lleras, C. (2005). Path Analysis. Encyclopedia of Social Measurement, 3, 25-30. https://doi.org/10.1016/B0-12-369398-5/00483-7

Maden, C., Arikan, E., Telci, E. E., \& Kantur, D. (2012). Linking Corporate Social Responsibility to Corporate Reputation: A Study on Understanding Behavioral Consequences. Social and Behavioral Science, 58, 655-664.

https://doi.org/10.1016/j.sbspro.2012.09.1043

Nepal Government (2020). The Industrial Enterprises Act, 2076. Kathmandu: Ministry of Industry, Commerce and Suppliers. Retrieved from Ministry of Industry, Commerce and Suppliers.

https://moics.gov.np/uploads/shares/laws/Industrial\%20Enterprises\%20Act\%20\%2020 20.pdf

Nunnally, J. C. (1978). Psychometric Theory(2d ed.). McGraw-Hill.

Pant, D. R., \& Piansoongnern, O. (2017). Impact of Corporate Social Responsibility on Sustainable Competitive Advantage: A Case Study of Leading Noodle Companies in Nepal. International Journal of Social Sciences and Management, 4, 275-283. https://doi.org/10.3126/ijssm.v4i4.17940

Russo, M. V., \& Fouts, P. A. (1997). A Resource-Based Perspective on Corporate Environmental Performance and Profitability. Academy of Management Journal, 40, 534-559. https://doi.org/10.2307/257052

Saeidi, S. P., Sofian, S., Saeidi, P., Saeidi, S. P., \& Saaeidi, S. A. (2015). How Does Corporate Social Responsibility Contribute to Firm Financial Performance? The Mediating Role of Competitive Advantage, Reputation, and Customer Satisfaction. Journal of Business Research, 68, 341-350. https://doi.org/10.1016/j.jbusres.2014.06.024

Schreiber, J. B., Nora, A., Stage, F. K., Barlow, E. A., \& King, J. (2006). Reporting Structural Equation Modeling and Confirmatory Factor Analysis Results: A Review. The Journal of Educational Research, 99, 323-338.

https://doi.org/10.3200/JOER.99.6.323-338 
Schwaiger, M. (2004). Components and Parameters of Corporate Reputation-An Empirical Study. Schmalenbach Business Review, 56, 46-71. https://doi.org/10.1007/BF03396685

Shamma, H. M. (2012). Toward a Comprehensive Understanding of Corporate Reputation: Concept, Measurement and Implications. International Journal of Business and Management, 7, 151-169. https://doi.org/10.5539/ijbm.v7n16p151

Sigdel, B., \& Amponstira, F. (2020). Effect of Corporate Social Responsibility on Firms Profitability: A Study on Small and Medium Enterprises in Pokhara City, Nepal. International Business Research, 13, 1-76. https://doi.org/10.5539/ibr.v13n10p76

Sindhu, M. I., \& Arif, M. (2017). The Inter Linkage of Corporate Reputation between Corporate Social Responsibility and Financial Performance. Pakistan Journal of Commerce and Social Sciences (PJCSS), 11, 898-910. http://hdl.handle.net/10419/188321

Singh, P. J., Sethuraman, K., \& Lam, J. Y. (2017). Impact of Corporate Social Responsibility Dimensions on Firm Value: Some Evidence from Hong Kong and China. Sustainability, 9, 15-32. https://doi.org/10.3390/su9091532

Spillan, J., \& Parnell, J. (2006). Marketing Resources and Firm Performance among SMEs. European Management Journal, 24, 236-245.

https://doi.org/10.1016/j.emj.2006.03.013

Stainer, L. (2006). Performance Management and Corporate Social Responsibility: The Strategic Connection. Strategic Change, 15, 253-264. https://doi.org/10.1002/jsc.761

Stanaland, A. J., Lwin, M. O., \& Murphy, P. E. (2011). Consumer Perceptions of the Antecedents and Consequences of Corporate Social Responsibility. Journal of Business Ethics, 102, 47-55. https://doi.org/10.1007/s10551-011-0904-Z

Surroca, J., Tribo, J. A., \& Waddock, S. (2010). Corporate Responsibility and Financial Performance: The Role of Intangible Resources. Strategic Management Journal, 31, 463-490. https://doi.org/10.1002/smj.820

Teoh, S. H., Welch, 1., \& Wazzan, C. P. (1999). The Effect of Socially Activist Investment Policies on the Financial Markets: Evidence from the South African Boycott. The Journal of Business, 72, 35-89. https://doi.org/10.1086/209602

Yamane, T. (1967). Statistics: An introductory Analysis. Harper and Row. 